\title{
Net Fisheries' Métiers in the Eastern Mediterranean: Insights for Small-Scale Fishery Management on Kalymnos Island
}

\author{
Kyriakoula Roditi * and Dimitris Vafidis
}

Oceanography Laboratory, Department of Ichthyology and Aquatic Environment, University of Thessaly, Fytoko Street, Nea Ionia, Volos 38445, Greece

* Correspondence: roditi@uth.gr; Tel.: +24-210-930-53

Received: 12 April 2019; Accepted: 18 July 2019; Published: 21 July 2019

\begin{abstract}
Small-scale fisheries constitute an important component of coastal human societies. The present study describes the small-scale net fisheries on Kalymnos Island (south-east Aegean Sea) that harbors the largest small-scale fleet in the eastern Mediterranean Sea. In addition, this study aims to evaluate their characteristics and economics. Relevant métiers were identified through a multivariate analysis by inputting the main resources and fishing gear data that were recorded during landings. Four main practices were observed being used as fishing gears, gillnets and trammel nets, targeting the species Mullus barbatus, Boops boops, Mullus surmuletus, Scorpaena porcus, and Sepia officinalis. Further analysis, which incorporated data concerning the type of the gear used, revealed 11 distinct métiers. Most of these métiers are practiced by other Mediterranean small-scale fisheries as well, in terms of target species, gear and seasonality. However, the métier that had its target species as B.boops is not practiced in other Mediterranean small-scale fisheries. The seasonal rotation of métiers was determined by the availability of different species rather than their market price. The results revealed the difference in fishing practice used by the fishermen in the study area compared to other fishing practices in the Mediterranean Sea. In particular, the fishermen of this study area targeted more species (B.boops) with a very low market price. They also provided essential information for the development and implementation of management plans aiming at the sustainability of small-scale fisheries.
\end{abstract}

Keywords: landing data; small-scale fishery; multivariate analysis; economic indicators; métier; net

\section{Introduction}

Great variations were presented in the small-scale fishery from one area to another, which is not only due to the biological and environmental conditions, but is also affected by the social, economic, and historical context in which fishermen live. As far as the fisheries in the Mediterranean are concerned, a significant part of them is represented by small-scale fishery [1]. Moreover, it is widely proven that in several areas of the world, small-scale fishery contributes significantly to poverty reduction and to the sustainable development of the economy, as well as provides an important source of food to people [2]. The design of an impartial and accurate monitoring scheme for the small-scale fishery is a complicated procedure. This is due to the fact that it presents a large number of fishing vessels and activities along with an extended coastline (where the fishing activities take place) and the usual practice of directly supplying the landings to local markets [3-5].

Each fishing practice involves a set of specific features, since the skipper has to make a number 3of choices before each fishing trip. He must select target species, fishing location, and fishing gear, making his decisions according to the season of the year, the weather, and the market prices [6]. In the 
literature, these combinations of features are termed as métiers [7], fishing strategies [8], or fishing tactics [9]. The identification of metiers is based on the analysis of the species composition from the large database of each fishing activity, which is available from logbooks or from collecting landing data $[8,10-12]$.

It is important to know the fishing tactics and strategies, as well as their impact on fish stocks, in order to manage small-scale fisheries [6]. In the Mediterranean Sea, a study on several aspects of small-scale fishery was carried out in Spain which identified and described the characteristics of small-scale fisheries based on logbooks and presented an analysis of the fishing activity which used the following fishing gear: trammel net, gillnet, and longline [13-16]. A description of the characteristics of the artisanal fisheries, which, based their activity in space and time, took place around the Tabarca Marine Reserve [17]. Trawling fishery, effort characteristics, landings profile, and métiers were identified [11,18-21]. Another research on the fishing activity and effort of small-scale fisheries was carried out in French Mediterranean marine-protected areas (MPA) [22]. Furthermore, a second research in France presented métiers and catch profiles from seven major pelagic and demersal French fleets [23]. These characteristics of the fishing effort, fleet, and identification métiers were also identified in the southern Tyrrhenian Sea [24] and southern European waters [25].

Other studies, however, take into consideration the different type of gears [26-28]. Particularly, in the eastern Mediterranean Sea, very few studies have been carried out, mostly covering the Hellenic Seas. These studies either presented an overview of the most important small-scale fisheries métiers in Greece [26,29-32] or comprehensively analyzed métiers in specific areas, for example, in Patraikos [27] and in Korinthiakos [28] gulfs, which presented case-studies.

The market price of species is an important factor determining the choice of the fishing tactics that fishermen choose $[2,33,34]$. For this reason, the study of economic data may be an additional element in implementing management measures for small-scale fishery and for the conservation of fish stocks. However, the lack of financial data is often a major obstacle to research the economic viability of fisheries [2,35]. There are, though, studies which research the relationship between the supply and the demand dynamics of given species at a given time [33,36,37]. According to [34], here are economic indicators which calculate the economic sustainability of fishing vessels.

The harbors of Kalymnos Island (Dodecanese, South-east Aegean Sea) have the largest and the most active small-scale coastal fleet in the eastern Mediterranean Sea [38]. Four main types of fishing gears were used: longlines $(42.5 \%)$, nets $(54.4 \%)$, traps $(1.3 \%)$, and beach seines $(1.9 \%)$. The percentages were calculated according to the data from the fleet register of the common fishery policy [38]. Based on these data, nets are the most widely utilized by fishermen. Despite the general acknowledgement of Kalymnos as a fishery society [2,38], there has not been a specific study completed so far to analyze the associated métiers.

Considering all of the above, the present study aims to identify, analyze, and combine the main métiers, as well as their associated economic indicators, which were practiced with different types of net fisheries (gillnet, trammel net, and combined nets) on Kalymnos Island, which is one of the most important and representative Mediterranean area for small-scale fisheries.

\section{Materials and Methods}

\subsection{Sampling}

The fishing activity of the small-scale fleet of Kalymnos (Greece), that uses every kind of artisanal fishery and operates in the marine area of Dodecanese Island complex, south-east Aegean Sea, was monitored during a 16-month period, from February 2013 to May 2014 (32 boats). In the fishery port of Kalymnos, data were collected by interviewing fishermen during landings $[3,22]$ on three randomly selected days within each month. Accordingly, the collection of landing data was conducted by interviewing the fishermen on the arrival of vessels and not by downloading their logbooks [23]. This is the most common and the only feasible method of sampling practice [29]. 
Nets vessels typically carry out daily fishing trips of 2 to $48 \mathrm{~h}(9 \pm 6 \mathrm{~h})$ and come back to their homeport to sell their catch (Figure 1), as in other Mediterranean fisheries [17,39]. For each fishing operation the following data were recorded: (i) the target species, (ii) the type of the gear and its technical characteristics (mesh size for nets), (iii) the depth of the fishing ground, (iv) the number of crew member, $(\mathrm{v})$ the weight of total catch and of each species $(\mathrm{kg})$, and (vi) the market price $(€ / \mathrm{kg})$ of each species. Complete information on the characteristics of the fishing vessels (length (LOA), gross tonnage (GRT), engine power (HP)) was also recorded. Over the study period, 315 fishing operations were recorded. After excluding zero-species operations, 286 fishing operations were used for further analysis, and for the final analysis, 260 fishing operations were analyzed (Bray-Curtis coefficient).

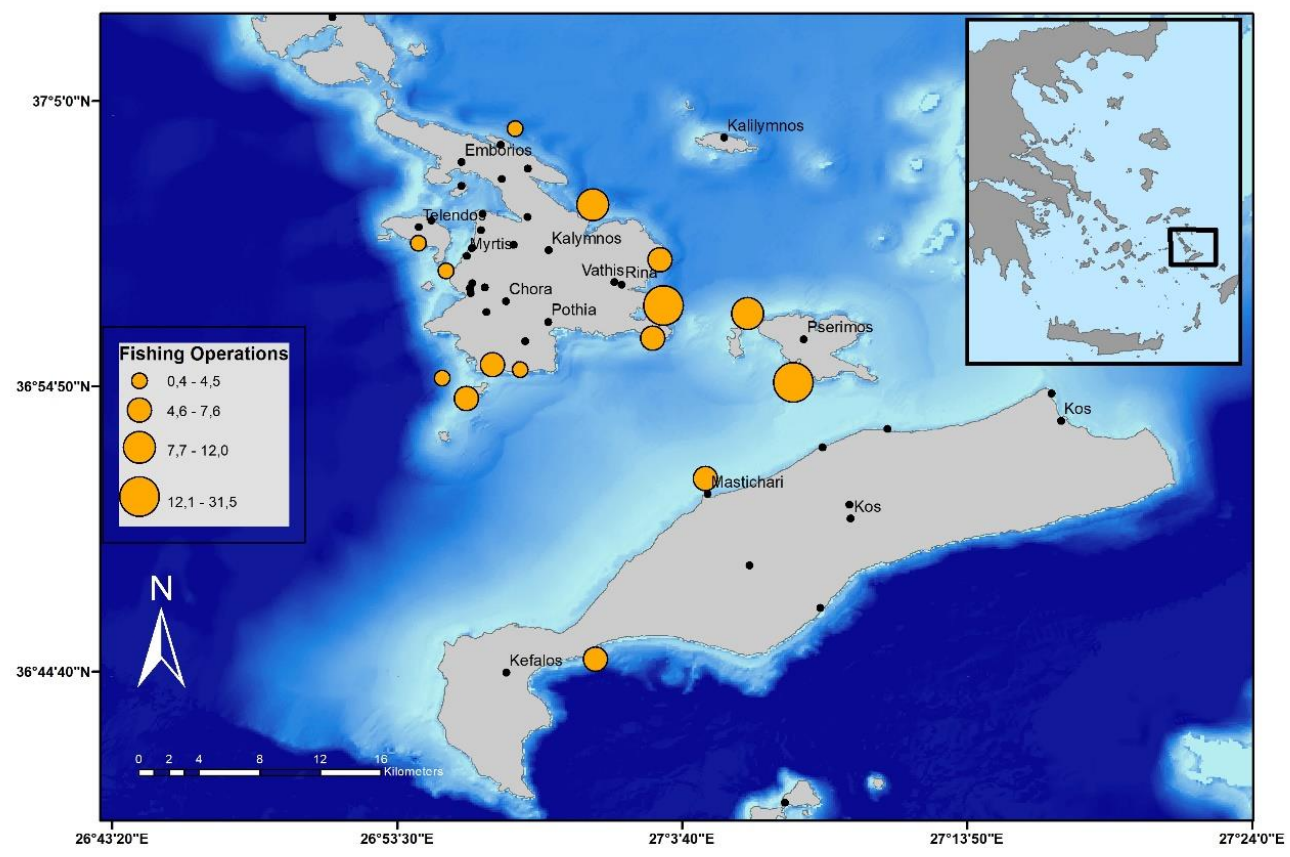

Figure 1. Percentage of fishing operations in the surrounding area of Kalymnos Island.

\subsection{Multivariate Analysis}

Data were analyzed under a multivariate approach [8] to identify fisheries métiers, applying a principal component analysis (PCA). Hierarchical cluster analysis (HCA), using Euclidean distance and Ward's aggregation method, was used to classify the catch profiles and to identify relevant groups representing different fisheries strategies with respect to species, season(s), fishing ground (depth), and technical characteristics of the gear (i.e., number and size of hooks). Zero-species operations and species caught in only one or two operations were excluded from the analysis. In all fishing operations of a specific gear type, the persistent targeting of the same species was a priori considered as forming a distinct métier [27].

Cluster groups with a small proportion of fishing activities were removed for the fishing gear set, and thus, the data matrix was transformed having rows as species and columns as fishing days; data input was total catch $(\mathrm{kg})$. Data were analyzed from a triangular similarity matrix by applying the Bray-Curtis coefficient, and then subjected to hierarchical cluster analysis using the average linkage method to identify relevant groups according to target-species [13,28]. A 50\% level ensured that most important species were actually included in the description of each métier [18], whereas the $20 \%$ dissimilarity level was set as a cut off value.

\subsection{Economic Performance Indicators}

The assessment of economic performance is a key element in the further understanding of the economic incentives that exist in the fishery industry. In this study research, economic performance 
indicators are based on the costs and earnings of 32 vessels, which participated in this study. The collection of economic data was carried out by using a questionnaire with the fishermen and by collecting the data of the fishing trips from all the boats which participated in the survey. The concepts of costs and earnings are of vital importance based on the profitability analysis of fishing vessels in industrialized countries [40].

The economic performance indicators are presented as follows, concerning the period 2013-2014 (16 complete months):

Gross revenue is defined as the landing value of each vessel during one year of fishing operations. They are the results of the average revenue of each trip multiplied with the number of fishing trips.

Variable costs are the total expenses of all the fishing trips in year, except for labor costs. They include costs of the fuel, the lubricant, the liquid gas, the bait, the food, and the minor repairs during the fishing period. They are the results of the average vessel variable cost per fishing trip multiplied with the number of days of each fishing trip.

Fixed cost is the total cost of the annual repair and maintenance cost of the boat, the engine, the fishing gear, and the other equipment on the vessel. Fixed cost is not changed by the number of fishing trips. Labor cost is the daily payment of the crew multiplied with the number of crew numbers employed per vessel for a trip, including the captain, taking into account the number of days the period trips last.

Number of crew size per trip is the number of crew members employed per vessel for a fishing trip, including the captain.

Income is defined as the difference between gross revenue and variable costs, except for the labor cost [Gross revenue - variable costs (except labor cost) $=$ income].

Gross value added (GVA) is referred as the difference between the annual gross revenue minus the total number of the annual variable costs and the fixed cost, excluding the labor costs again (Income - fixed cost $=$ gross value added)

Gross cash flow $(\mathrm{GCF})$ is an important performance indicator and it results from the gross revenue cists minus all the expenses (variable costs, fixed cost, and labor costs), [Gross revenue - all except $($ variable cost + fixed cost $)=$ Gross cash flow $]$.

Break-even revenue is the point of an enterprise where the total sales revenue is equal to the total costs. Here, there is neither profit nor damage, therefore it represents the point where costs and revenues are equal:

Break-even revenue $=$ fixed costs $($ vessel costs) $/$ (gross cash flow/gross revenue) [34,35,41-43].

In the case of the fishery activities with available economic data, an analysis based on the break-even revenue analysis can be applied. The gross cash flow (GCF), which is the gross production (income) minus all the costs (variable, fixed, and labor costs), is an important indicator in the sense that the fishermen will remain in the fishery activity as long as the gross cash flow is positive. On the other hand, they will remain in the fishery activity for a longer period only if the fixed costs are covered by the gross cash flow. The revenue in the cash flow that is exactly equal to the fixed costs can be defined as break-even revenue [35,44].

The economic viability and the ability of a segment of the fleet to have the best or the worst harvest in each fishing activity can be calculated taking into account the relationship between the actual revenue and the break-even revenue.

Gross cash flow is an indicator that a business runs smoothly. A high positive gross cash flow allows the company to make new investments and to design a new strategy for further development [34,35,41-43].

If the revenue of a segment of the fleet, taking into account every variable (a certain stock, species composition, total daily catch rates, and cost structure), shows lower prices than break-even revenue, then it may be non-economically viable for fishing, and vice versa. The economic viability and costs (percentage of investment costs) are important indicators which depend on the results of a certain fishing area. These indicators are significant and should be paid attention to, because they are variables 
frequently found in the fishery sector. Additionally, it is vital to gather data in a chronological order to balance changes caused by the alterations in fish situations, price, and costs.

The gross profit margin expresses the ratio of gross revenue and sales ( $\mathrm{kg}$ of fish). It determines the percentage (\%) of the gross profit margin, where an enterprise-in this specific case, the fishing fleet-markets the fish (product). It also determines whether the product is exploited and how its price is determined [Gross profit margin $=$ gross revenue - variable costs/gross revenue $(\%)$ ].

In the present study, each métier was considered as a business operating at a certain time (season) using specific fishing gear (gillnets and trammels nets) and targeting particular species. Nevertheless, all the species, which were caught with each métiers, were calculated. The economic indicators were calculated only with these four main métiers (Gill1, Gill2, Gill3, and Tr4). The métier Gill3 has not calculated the break-even revenue and gross profit margin, because it presented negative gross cash flow.

\section{Results}

On the whole, a total of 315 fishing operations and a total of 44 species ( 39 fish species, 2 crustaceans, and 3 cephalopods) using nets were recorded. After excluding zero-species operations, 286 fishing operations and 33 species remained for further analysis (11 species were not utilized for further analysis, because they appeared in the clusters which were not including in the final analysis).

The total amount of species caught, the weight $(\mathrm{kg})$, and the average market price $(€ / \mathrm{kg})$ for the métiers (Gill1, Gill2, Gill3, Gill4, Gill5, Tr1, Tr2, Tr3, Tr4, Comb1, Comb2) are presented in Table 1.

Table 1. The species caught, the weight $(\mathrm{kg})$, and the average market price $(€ / \mathrm{kg})$ for the four main métiers (Gill1, Gill2, Gill3, Gill4, Gill5, Tr1, Tr2, Tr3, Tr4, Comb1, and Comb2).

\begin{tabular}{|c|c|c|}
\hline Species & Total Weight (kg) & Mean Market Price $(€ / \mathrm{kg})$ \\
\hline Boops boops & 7640 & 2 \\
\hline Dentex dentex & 94.6 & 20 \\
\hline Diplodus annularis & 3 & 2 \\
\hline Diplodus puntazzo & 1.4 & 25 \\
\hline Diplodus sargus & 18 & 11 \\
\hline Diplodus vulgaris & 0.8 & 25 \\
\hline Engraulis encrasicholus & 10 & 3 \\
\hline Merluccius merluccius & 11 & 9 \\
\hline Mullus barbatus & 567 & 9 \\
\hline Mullus surmuletus & 429.1 & 15 \\
\hline Oblada melanura & 60 & 8 \\
\hline Pagellus acarne & 5 & 3 \\
\hline Pagellus erythrinus & 103 & 8 \\
\hline Pagrus pagrus & 51 & 22 \\
\hline Phycis blennoidas & 6 & 3 \\
\hline Sarda sarda & 20 & 3 \\
\hline Sardinella aurita & 86 & 2 \\
\hline Scomber colias & 13 & 3 \\
\hline Scorpaena elongata & 3 & 8.5 \\
\hline Scorpaena porcus & 500 & 9 \\
\hline Serranus cabrilla & 696.5 & 3 \\
\hline Serranus scriba & 47.5 & 3 \\
\hline Siganus luridus & 20 & 3 \\
\hline Siganus rivulatus & 107 & 3 \\
\hline Sparus aurata & 8.5 & 18 \\
\hline Sparisoma cretense & 228 & 8 \\
\hline Spicara smaris & 20.5 & 3 \\
\hline Spondyliosoma cantharus & 2.4 & 23 \\
\hline Trachinus draco & 6 & 8 \\
\hline Palinurus elephas & 185.5 & 25 \\
\hline Loligo vulgaris & 13 & 10 \\
\hline Octopus vulgaris & 276 & 5 \\
\hline Sepia officinalis & 413.5 & 5 \\
\hline
\end{tabular}


Active boats (32) with length ranges from 2.5 to $14.8 \mathrm{~m}$ (average $9.4 \pm 2.5 \mathrm{~m}$ ), with engine power ranging from 8.8 to $160 \mathrm{HP}$ (average $45.12 \pm 37.57 \mathrm{HP}$ ), and gross tonnage $(\mathrm{GT})$ ranging from 0.8 to 31.39 GT (average $6.7 \pm 5.8 \mathrm{GT}$ ).

The PCA of gillnet fishing trips' data revealed that eight principal components axes accounted for $72 \%$ of the total variation (Figure $2 \mathrm{a}$ ). The hierarchical cluster analysis of the above data based on these eight principal components led to the identification of eight clusters (Table 2). Trammel fishing trips' data revealed that nine principal components axes accounted for $68 \%$ of the total variation (Figure $2 b$ ). The hierarchical cluster analysis of the above data based on these nine principal components led to the identification of nine clusters (Table 3). Combined net fishing trips' data revealed that five principal components axes accounted for $62 \%$ (Figure $2 \mathrm{c}$ ). The hierarchical cluster analysis of the above data based on these five principal components led to the identification of five clusters (Table 4).

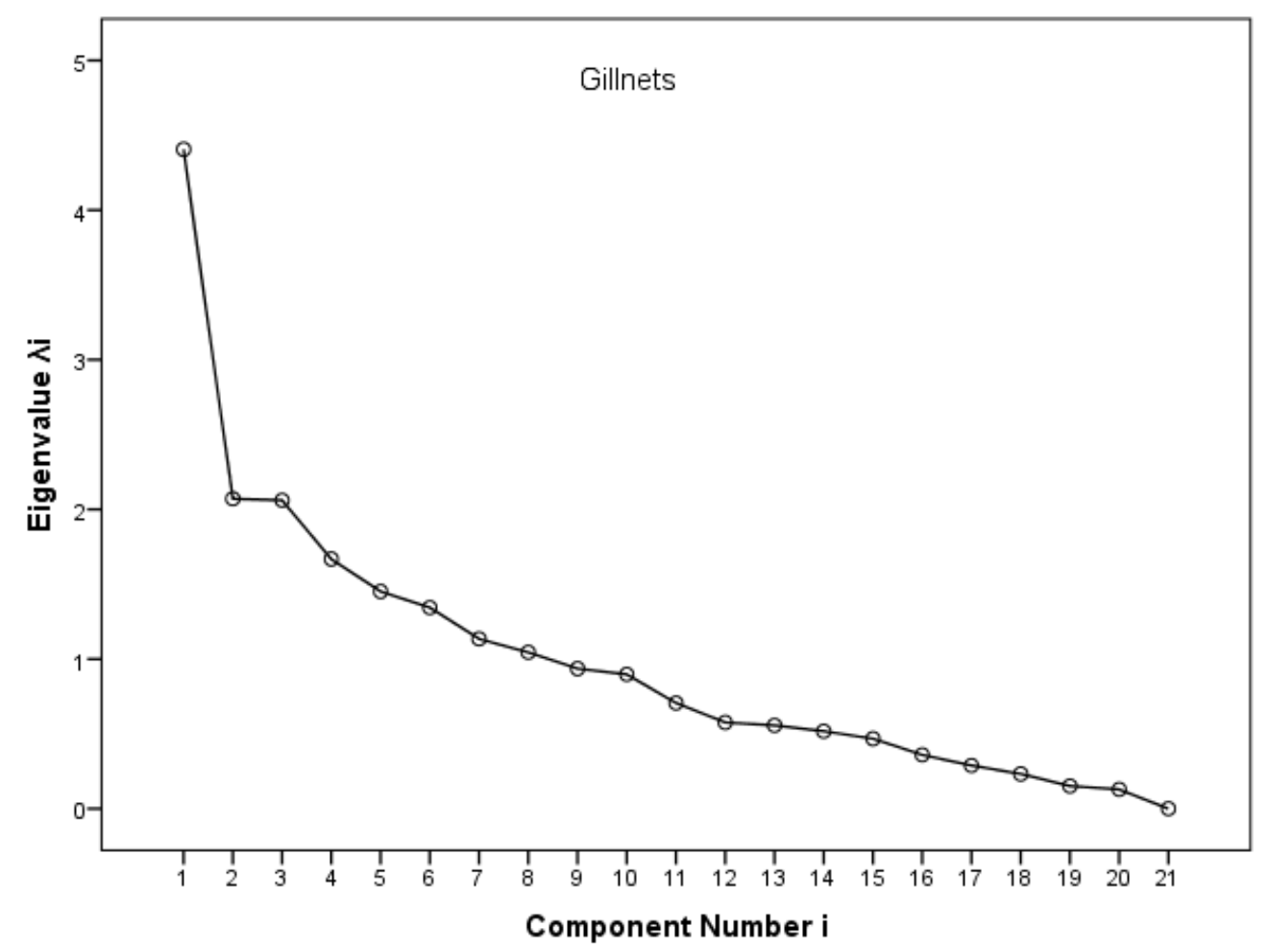

(a)

Figure 2. Cont. 


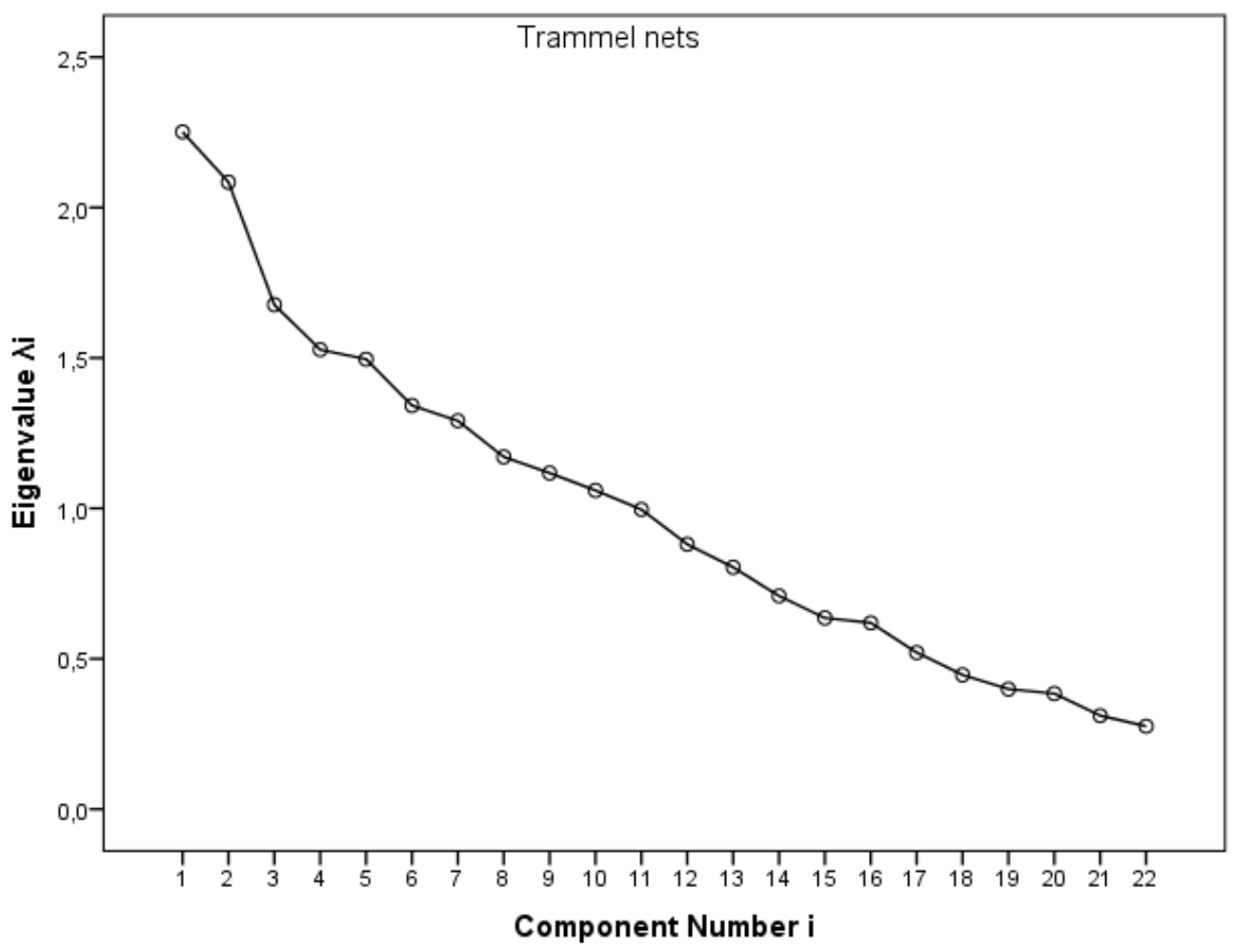

(b)

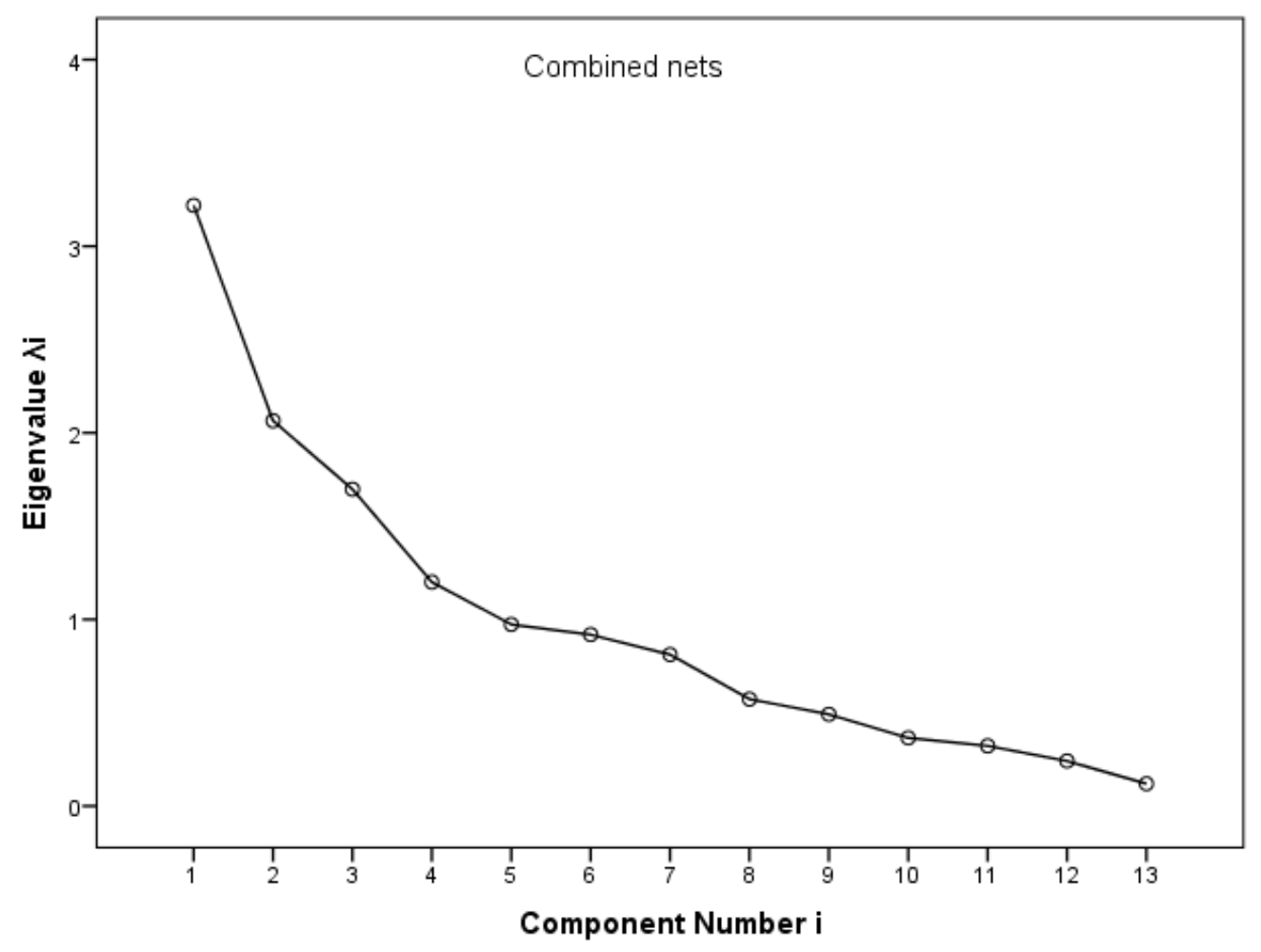

(c)

Figure 2. Screen diagrams for the landings profiles data matrices for (a) gillnets, (b) trammel nets, (c) combined gillnets-trammel nets fishing trips in south-east Aegean (Kalymnos Island, Dodecanese, Greece). 
Table 2. Average landing profiles of the identified clusters within gillnet, with a proportion in landings $>10 \%$ (in brackets, the contribution of each cluster, in $\%$, to total data variance within each fishing gear).

\begin{tabular}{|c|c|c|c|}
\hline \multirow[t]{2}{*}{ Species } & \multicolumn{3}{|c|}{ Species } \\
\hline & A $(38.7 \%)$ & & $\mathrm{F}(2.5 \%)$ \\
\hline \multirow[t]{3}{*}{ B.boops } & 100 & S.cretense & 100 \\
\hline & & S.cabrilla & 100 \\
\hline & B $(13.5 \%)$ & B.boops & 50 \\
\hline M.surmuletus & 100 & S.porcus & 50 \\
\hline B.boops & 50 & M.surmuletus & 50 \\
\hline S.cabrilla & 40.9 & M.barbatus & 25 \\
\hline \multirow[t]{3}{*}{ M.barbatus } & 13.6 & S.officinalis & 25 \\
\hline & & O.vulgaris & 25 \\
\hline & $C(4.3 \%)$ & D.dentex & 25 \\
\hline O.vulgaris & 85.7 & S.luridus & 25 \\
\hline M.surmuletus & 85.7 & & \\
\hline B.boops & 71.4 & & $\mathrm{G}(1.2 \%)$ \\
\hline S.cabrilla & 42.9 & S.porcus & 100 \\
\hline S.porcus & 28.6 & M.surmuletus & 100 \\
\hline D.vulgaris & 28.6 & P.elephas & 100 \\
\hline M.barbatus & 14.3 & T.draco & 100 \\
\hline S.aurita & 14.3 & S.sphyraena & 100 \\
\hline S.colias & 14.3 & S.cabrilla & 50 \\
\hline \multirow{3}{*}{ S.porcus } & 28.6 & P.erythrinus & 50 \\
\hline & & S.officinalis & 50 \\
\hline & $\mathrm{D}(1.2 \%)$ & D.dentex & 50 \\
\hline S.porcus & 100 & S.luridus & 50 \\
\hline S.officunalis & 100 & & \\
\hline S.luridus & 100 & & $\mathrm{H}(6.7 \%)$ \\
\hline \multirow[t]{3}{*}{ D.sargus } & 100 & O.melanura & 54.5 \\
\hline & & S.sarda & 45.5 \\
\hline & E $(31.9 \%)$ & B.boops & 27.3 \\
\hline M.barbatus & 98.1 & S.porcus & 27.3 \\
\hline S.cabrilla & 40.4 & P.pagrus & 27.3 \\
\hline B.boops & 34.6 & S.cabrilla & 18.2 \\
\hline S.aurita & 15.4 & O.vulgaris & 18.2 \\
\hline \multirow[t]{2}{*}{ P.erythrinus } & 11.5 & M.surmuletus & 18.2 \\
\hline & & D.dentex & 18.2 \\
\hline
\end{tabular}

Table 3. Average landing profiles of the identified clusters within trammel net, with a proportion in landings $>10 \%$ (in brackets, the contribution of each cluster, in $\%$, to total data variance within each fishing gear).

\begin{tabular}{|c|c|c|c|c|c|}
\hline Species & & Species & & Species & \\
\hline & A $(33.3 \%)$ & & E $(3.2 \%)$ & & $\mathrm{H}(6.5 \%)$ \\
\hline M. surmuletus & 67.7 & N. norvegicus & 100 & O. melanura & 83.3 \\
\hline S. cabrilla & 64.5 & S. porcus & 66.7 & S. porcus & 66.7 \\
\hline S. porcus & 54.8 & M. surmuletus & 66.7 & S. cretense & 50.0 \\
\hline O. vulgaris & 32.3 & S. officinalis & 66.7 & M. surmuletus & 33.3 \\
\hline S. officinalis & 29.0 & S. cretense & 66.7 & O. vulgaris & 33.3 \\
\hline S. cretense & 25.8 & D. dentex & 33.3 & D. sargus & 33.3 \\
\hline \multirow[t]{2}{*}{ S. luridus } & 12.9 & P. erythrinus & 33.3 & Z. faber & 16.7 \\
\hline & B $(25.8 \%)$ & & $\mathrm{F}(15.1 \%)$ & & $\mathrm{I}(3.2 \%)$ \\
\hline S. porcus & 91.7 & M. surmuletus & 78.6 & S. ocellatus & 100 \\
\hline S. officinalis & 70.8 & S. cabrilla & 57.1 & S. porcus & 66.7 \\
\hline S. cabrilla & 58.3 & P. erythrinus & 50.0 & S. officinalis & 66.7 \\
\hline D. dentex & 54.2 & S. porcus & 35.7 & S. scriba & 66.7 \\
\hline M. surmuletus & 33.3 & M. barbatus & 28.6 & D. dentex & 33.3 \\
\hline P. elephas & 37.5 & M. merluccius & 28.6 & P. elephas & 33.3 \\
\hline S. cretense & 20.8 & Z. faber & 21.4 & P. pagrus & 33.3 \\
\hline
\end{tabular}


Table 3. Cont.

\begin{tabular}{|c|c|c|c|}
\hline Species & & Species & Species \\
\hline P.pagrus & 29.2 & S. offricinalis & 21.4 \\
\hline O. vulgaris & 12.5 & S. cretense & 14.3 \\
\hline \multirow[t]{3}{*}{ S. scriba } & 12.5 & O. vulgaris & 14.3 \\
\hline & & S. scriba & 14.3 \\
\hline & C (3.2\%) & & \\
\hline M. cephalus & 100 & & $\mathrm{G}(3.2 \%)$ \\
\hline S. cabrilla & 33.3 & M. surmuletus & 100 \\
\hline S. officinalis & 33.3 & D. vulgaris & 100 \\
\hline \multirow{3}{*}{ S. cretense } & 33.3 & S. officinalis & 100 \\
\hline & & S. cabrilla & 100 \\
\hline & $\mathrm{D}(6.5 \%)$ & D. sargus & 66.7 \\
\hline S. rivulatus & 100 & O. vulgaris & 33.3 \\
\hline S. cretense & 66.7 & & \\
\hline S. porcus & 50.0 & & \\
\hline M. surmuletus & 33.3 & & \\
\hline S. officinalis & 33.3 & & \\
\hline D. dentex & 33.3 & & \\
\hline
\end{tabular}

Table 4. Average landing profiles of the identified clusters within combined net, with a proportion in landings $>10 \%$ (in brackets, the contribution of each cluster, in $\%$, to total data variance within each fishing gear).

\begin{tabular}{|c|c|c|c|}
\hline \multirow[t]{2}{*}{ Species } & \multicolumn{3}{|c|}{ Species } \\
\hline & $\mathrm{A}(22.2 \%)$ & & $\mathrm{D}(41.7 \%)$ \\
\hline S.officinalis & 100 & M.barbatus & 86.7 \\
\hline B.boops & 87.5 & S.cabrilla & 80.0 \\
\hline M.surmuletus & 50.0 & S.cretense & 80.0 \\
\hline S.cabrilla & 37.5 & M.surmuletus & 40.0 \\
\hline O.vulgaris & 25.0 & S.aurita & 40.0 \\
\hline S.porcus & 25.5 & O.vulgaris & 26.7 \\
\hline \multirow[t]{3}{*}{ M.barbatus } & 12.5 & B.boops & 20.0 \\
\hline & & S.officinalis & 13.3 \\
\hline & B $(5.6 \%)$ & S.porcus & 13.3 \\
\hline M.surmuletus & 100 & & \\
\hline B.boops & 100 & & E $(8.3 \%)$ \\
\hline M.barbatus & 100 & M.surmuletus & 100 \\
\hline S.officinalis & 100 & S.colias & 100 \\
\hline O.vulgaris & 100 & S.cabrilla & 66.7 \\
\hline P.erythrinus & 100 & O.vulgaris & 66.7 \\
\hline S.porcus & 100 & S.porcus & 66.7 \\
\hline P.pagrus & 100 & M.barbatus & 33.3 \\
\hline S.colias & 100 & S.cretense & 33.3 \\
\hline \multirow[t]{3}{*}{ S.cabrilla } & 50.0 & S.officinalis & 33.3 \\
\hline & & P.pagrus & 33.3 \\
\hline & $C(22.2 \%)$ & S,scriba & 33.3 \\
\hline M.surmuletus & 100 & & \\
\hline B.boops & 100 & & \\
\hline M.barbatus & 100 & & \\
\hline S.officinalis & 100 & & \\
\hline O.vulgaris & 100 & & \\
\hline P.erythrinus & 100 & & \\
\hline S.porcus & 100 & & \\
\hline P.pagrus & 100 & & \\
\hline S.cabrilla & 50.0 & & \\
\hline
\end{tabular}


Multivariate analysis, irrespectively of the type of gillnet used, identified five métiers: Gill1, Gill2, Gill3, Gill4, and Gill5 (Figure 3a), the type of trammel net identified four métiers: $\operatorname{Tr} 1, \operatorname{Tr} 2$, $\operatorname{Tr} 3$, and $\operatorname{Tr} 5$ (Figure 3b), and the type of combined nets identified two métiers: Comb1 and Comb2 (Figure 3c). Therefore, taking also into account the type of gillnet used as fishing gear, the number of métiers increases to 5 métiers partition, but not significantly, seasonally. Métiers Gill1, Gill2, and Gill3 were practiced by both small $(<12 \mathrm{~m})$ and large vessels $(>12 \mathrm{~m})$, while métiers Gill4 and Gill5 were only practiced by the former. The type of trammel net used as fishing gear (the number of métiers increase to 4 métiers) presented instance fishing activity in the same season (spring and summer). Métiers $\operatorname{Tr} 1$, $\operatorname{Tr} 2$, $\operatorname{Tr} 3$, and $\operatorname{Tr} 4$ were practiced by both small $(<12 \mathrm{~m})$ and large vessels $(>12 \mathrm{~m})$. The type of combined nets used as fishing gear (the number of métiers increases to 2 métiers) presented the same activity seasonally (autumn and winter). Métier Comb2 was practiced by both small $(<12 \mathrm{~m})$ and large vessels (>12 m), while métier Comb1 was only practiced by the former (Table 5).

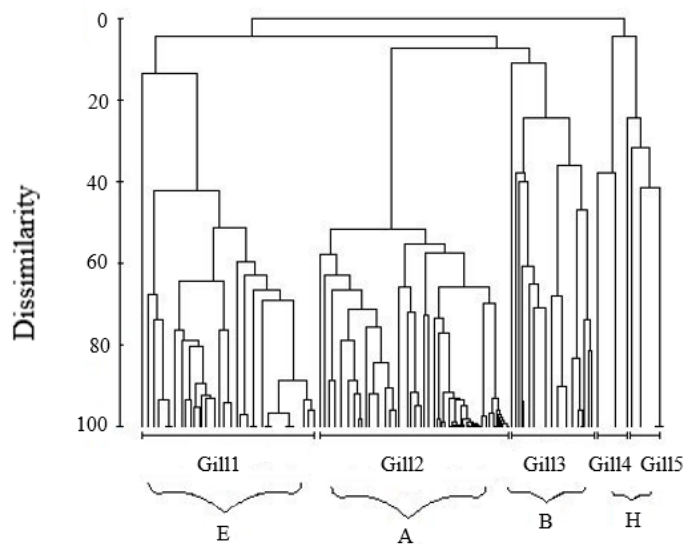

Fishing operations

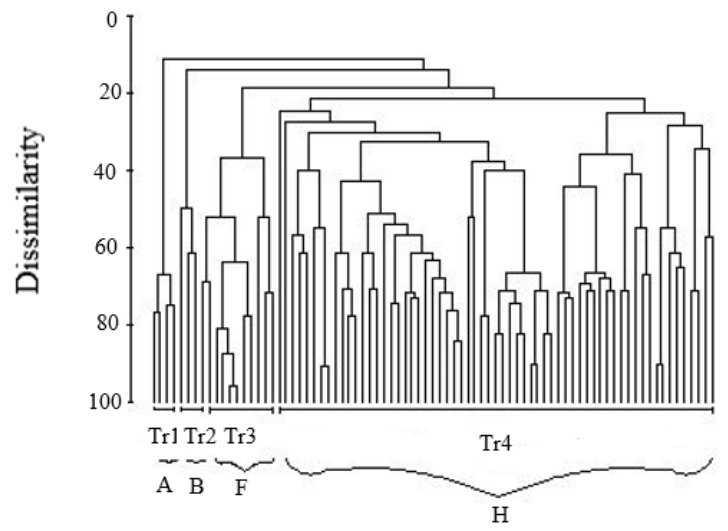

Fishing operations

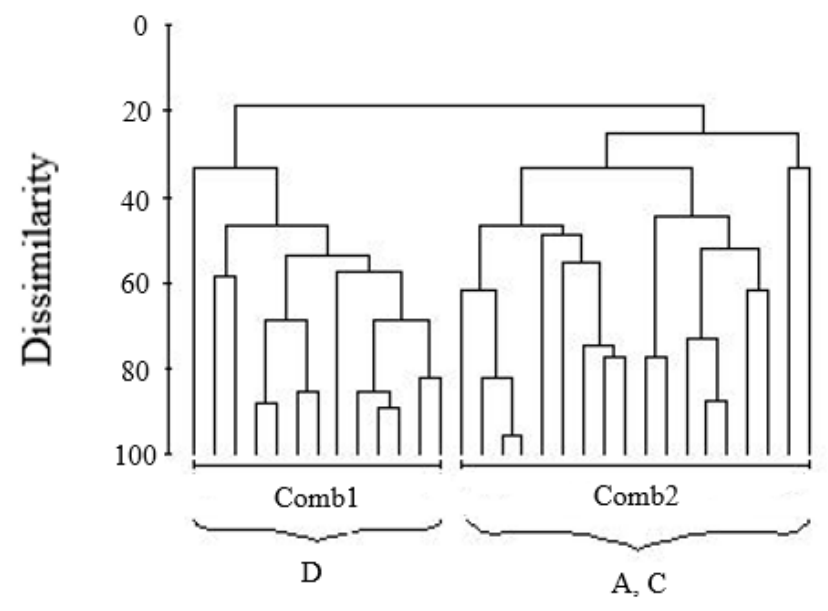

Fishing operations

Figure 3. Dendrogram of nets fishing operations in the south-east Aegean Sea (Kalymnos Island, Dodecanese, Greece), based on Bray-Curtis coefficient landings profiles. Eleven clusters (Gill1, Gill2, Gill3, Gill4, Gill5, Tr1, Tr2, Tr3, Tr4, Comb1, and Comb2) were identified, with fishing gear gillnets, trammel nets, and combined nets representing different landings profiles. The brackets represent the clusters from the first analysis. 
Table 5. Description of the identified 11 métiers (Gill1, Gill2, Gill3, Gill4, Gill5, Tr1, Tr2, Tr3, T4, Comb1, and Comb2), by fishing gear gillnets, trammel nets, and combined nets in the area of south-east Aegean Sea (Kalymnos Island, Greece).

\begin{tabular}{|c|c|c|c|c|c|c|c|c|}
\hline \multirow[t]{2}{*}{ Métiers } & \multirow[t]{2}{*}{$\begin{array}{l}\text { Number of } \\
\text { Operations }\end{array}$} & \multirow[t]{2}{*}{ Mean Species } & \multicolumn{2}{|c|}{$\begin{array}{c}\text { Percentage of } \\
\text { Operations by Vessel } \\
\text { Size }\end{array}$} & \multirow{2}{*}{$\begin{array}{l}\text { Month } \\
\text { Peak }\end{array}$} & \multicolumn{2}{|c|}{ Depth } & \multirow{2}{*}{$\begin{array}{c}\begin{array}{c}\text { Mesh Size } \\
(\mathrm{mm})\end{array} \\
\text { Peak }\end{array}$} \\
\hline & & & $<12 \mathrm{~m}$ & $>12 \mathrm{~m}$ & & Range & Peak & \\
\hline Gill1 & 35 & M. barbatus (100\%) & 94.3 & 5.7 & July-December & $27-84$ & $54-65$ & 18 \\
\hline Gill2 & 87 & B. boops $(98.9 \%)$ & 85.1 & 14.9 & December-February & $2-91$ & $50-64$ & 26 \\
\hline Gill3 & 19 & M. surmuletus (100\%) & 78.9 & 21.1 & October-December & $36-91$ & $42-49$ & 18,19 \\
\hline Gill4 & 2 & $\begin{array}{c}\text { S. sarda }(100 \%) \text {, P. pagrus }(50 \%), \\
\text { S. cabrilla }(50 \%)\end{array}$ & 100 & 0 & February & $18-64$ & $18-64$ & $34,36,45$ \\
\hline Gill5 & 5 & O. melanura $(100 \%)$ & 100 & 0 & May-June & $5-73$ & $5-73$ & 32,34 \\
\hline $\operatorname{Tr} 1$ & 4 & $\begin{array}{c}\text { S. luridus }(100 \%), \\
\text { S. cretense }(50 \%), \text { S. porcus } \\
(50 \%), \text { D. dentex }(50 \%)\end{array}$ & 75 & 25 & August & $4-110$ & $27-55$ & $23,24,26$ \\
\hline $\operatorname{Tr} 2$ & 3 & S. officinalis (100\%) & 66.7 & 33.3 & April & $18-64$ & $18-37$ & $24,26,28$ \\
\hline $\operatorname{Tr} 3$ & 11 & M. surmuletus $(100 \%)$ & 72.7 & 27.3 & April, August-September & $18-200$ & 70 & 24,26 \\
\hline $\operatorname{Tr} 4$ & 63 & $\begin{array}{c}\text { S. porcus }(69.8 \%) \\
\text { S. officinalis }(66.7 \%)\end{array}$ & 87.3 & 12.7 & April-May & $9-165$ & 37 & 26 \\
\hline Comb1 & 13 & $\begin{array}{l}\text { M. barbatus }(100 \%) \\
\text { S. cretense }(84.6 \%)\end{array}$ & 100 & 0 & September & $15-73$ & $54-66$ & $18,19,24,26,28$ \\
\hline Com2 & 18 & $\begin{array}{c}\text { B. boops }(88.9 \%) \\
\text { M. surmuletus }(72.2 \%)\end{array}$ & 77.8 & 22.2 & September,January-February & $15-91$ & $60-64$ & 24,26 \\
\hline
\end{tabular}


Métiers Gill1 (M. barbatus), Gill2 (B. boops), Gill3 (M. surmuletus), Gill5 (O. melanura), Tr2 (S. officinalis), and $\operatorname{Tr} 3$ (M. surmuletus) targeted to one single target species, whereas Gill4, $\operatorname{Tr} 1, \operatorname{Tr} 4$, Comb1, and Comb2 targeted more than one species. $\operatorname{Tr} 1, \operatorname{Tr} 2$, and $\operatorname{Tr} 4$ used trammel nets to catch mainly S. porcus and S. officinalis. Gill1, Gill2, and Gill3 were concurrently deployed, but caught different species: M. barbatus, B.boops, and M. surmuletus, respectively.

Table 6 presents economic and technical data for the main 4 métiers (Gill1, Gill2, Gill3, and Tr4), which were identified for the 32 vessels which participated in this study. The fishing gears which were used were gillnets and trammel nets. The métiers were not heterogeneous in terms of technical and operational characteristics. Métier Gill2 presented higher prices for all indicators other than métiers Gill1 and Gill3, except from the index gross value added which presented negative price, such as the métier Gill3. The results of the calculation of the economic indicators show that métier Tr4 presented higher prices for all the indicators than other métiers (Gill1, Gill2, Gill3, and Tr4).

Table 6. Main technical characteristics and economic indicators for the four main métiers which were identified (Gill1, Gill2, Gill3, and Tr4), in the area of Kalymnos Island, in the period between February 2013 to May 2014.

\begin{tabular}{ccccc}
\hline & \multicolumn{3}{c}{ Métiers } \\
\hline & Gill1 & Gill2 & Gill3 & Tr4 \\
\hline Engine power $(\mathrm{HP})$ & $47.91 \pm 56$ & $55.21 \pm 43.28$ & $62.94 \pm 43.39$ & $52.76 \pm 45.26$ \\
Gross tonnage (GT) & $6.77 \pm 4.48$ & $7.85 \pm 6.97$ & $9.93 \pm 8.68$ & $8.05 \pm 7.22$ \\
Length (m) & $9.79 \pm 2.66$ & $9.99 \pm 2.48$ & $10.93 \pm 2.45$ & $10.14 \pm 2.46$ \\
Number of crew size per trip (person) & $2 \pm 1$ & $2 \pm 0.8$ & $2 \pm 1$ & $2 \pm 0.9$ \\
Gross revenue $(€)$ & $3.138 \pm 894$ & $19.594 \pm 16.220$ & $2.202 \pm 1.576$ & $26.155 \pm 32.030$ \\
Variable cost $(€)$ & $1.761 \pm 825$ & $4.815 \pm 3.142$ & $985 \pm 439$ & $4.984 \pm 3.834$ \\
Income $(€)$ & $-1.377 \pm 874$ & $14.778 \pm 15.023$ & $1.216 \pm 1.605$ & $21.171 \pm 32.405$ \\
Fixed cost (annual) $(€)$ & $1.700 \pm 346$ & $1.662 \pm 903$ & $1.794 \pm 881$ & $1.600 \pm 821$ \\
Gross value added $(€)$ & $322 \pm 955$ & $-4.815 \pm 3.142$ & $-578 \pm 930$ & $19.571 \pm 32.373$ \\
Labor cost $(€)$ & $2.450 \pm 1.084$ & $5.515 \pm 2.641$ & $1.308 \pm 506$ & $3.685 \pm 1.979$ \\
Gross cash flow $(€)$ & $2.772 \pm 1.276$ & $7.600 \pm 14.965$ & $-1.887 \pm 1.309$ & $15.886 \pm 32.444$ \\
\hline
\end{tabular}

By assuming that each métier is a business, we calculated the break-even revenue and the gross profit margin of each fishing activity concerning a specific period of time. The results are presented in Table 7.

Table 7. Break-even revenue and gross profit margin for the four main metiers which were identified (Gill1, Gill2, Gill3, and Tr4).

\begin{tabular}{lcccc}
\hline & \multicolumn{4}{c}{ Métiers } \\
\hline & Gill1 & Gill2 & Gill3* & Tr4 \\
\hline Break-even revenue $(€)$ & 1.924 & 2.129 & - & 2.634 \\
Gross profit margin $(\%)$ & 43.87 & 75.42 & - & 80.94 \\
\hline
\end{tabular}

* The metier Gill3 has not calculated the break-even revenue and gross profit margin because it presented negative gross cash flow.

\section{Discussion}

The small-scale coastal net fishery on Kalymnos Island practiced 11 métiers in the period from February 2013 to May 2014. The fishing tactics correspond to gillnets, trammel nets, and combined nets. Most métiers are used at specific times of the year, with a seasonal rotation dictated by the availability of the target species. The vessels in the fleet, which the small-scale fisheries consist of, have the following characteristics: boats mean size $(<10 \mathrm{~m})$, engine power $(<45 \mathrm{HP})$, and tonnage $(<10 \mathrm{GRT})$, generally practice all of the various métier that are traditional in the area. However, some vessel of the fleet form métiers, practiced far from the harbor. The fishing took place in multiple fishing grounds close to the coast and tended to be carried out by larger vessels $[16,27]$. 
Métiers are seasonal and their catch per fishing trip remains relatively small, at less than $50 \mathrm{~kg}$ per fishing operation on average, with the exception of the species B. boops. The striped red mullet (Mullus surmuletus) métier Gill3 practically performed similarly during the same period, as did métier Gill2 with target species bogue (Boops boops).

Regarding our results concerning fisheries which used the métier Gill2 and the métier Gill3: métier Gill2 carried out the fishing activity near the harbor, while métier Gill3 carried out the fishing activity far from the harbor. Although, striped red mullet has a lower income price than bogue. This practice may prove that different fishing strategies and fishermen preferred this métier, which presents a lower risk [45]. Métier Gill2 used gillnet, presenting, as a result, higher gross cash flow, even though B. boops has a low market price. In this métier (Gill2), the break-even revenue was $2.129 €$, and for this reason the vessels that caught large amounts of $B$. boops succeeded in a satisfactory average gross cash flow $(7.600 \pm 14.965 €)$. This métier (Gill2) also coincides with the spawning period of the species and, combined with the increased fishing pressure, it is possible that it has negative consequences in the fish stock $[2,46]$.

One important métier present in the port of Vilanova (Spain) [16], the one targeting Sepia officinalis in spring and summer, was also present in this study, using the métier Tr2 with the same gear and at the same period (trammel net, spring). This activity raised the question of whether this métier is present throughout the Mediterranean. Sepia officinalis métier is also present in the Gulf of Patraikos, Greece [27], and in several areas of the Spanish coast with the trammel net in winter, spring, and summer [14,17,47].

Six of our 11 métier (Tr3, Tr4, Comb1, Gill1, Gill3, and Gill4) are presented in other Mediterranean small-scale fisheries in terms of target species, seasonality, and fishing gear. The métier $\operatorname{Tr} 3$, with similar species, seasonality, and trammel net fishery as in our study, are present in numerous other Mediterranean areas: in the Mallorca (Spain) [34], in the Majorca Island trammel net fishery [46], in the Alicante Gulf small-scale fishery [17], in the port of Vilanova (Spain) [12], in the Cote Bleue Marine Park (north-western, France) [22], and in the Cilento (South, Italy) artisanal fishery [48]. Métier Tr4, which uses trammel net to fish Scorpaena porcus, is similar to métier in the Majorca Island [49], although seasonality may differ slightly. Comb1 métier, which uses combined net (trammel net-gillnet) to fish Mullus barbatus, was also documented by Colloca et al. (2003) in Cilento (Italy). Gill1 and Gill3 métier, which use gillnet to fish $M$. barbatus and M. surmuletus, respectively, were also documented by Colloca et al. (2003) and Gill4, which used gillnet with target species Sarda sarda and has been identified in two areas of the Spanish coast $[14,17]$. Métier Gill2, which uses gillnet with only target species B. boops, has not been identified in other areas in the Mediterranean Sea. This proves that several métiers are extremely localized, being present in only a few ports or a single one [18]. However, other métiers, which target M. merluccius, are present throughout the Mediterranean $[14,16,17,24,27,28]$ but not present in the area of Kalymnos.

The present economic analysis shows that three out of four métiers were able to cover all costs (variable costs, fixed cost, and labor costs). Métiers Gill2 and Tr4 show that there was more economic sustainability. On the other hand, métiers Gill1 and Gill3, even though they targeted the species which have a high average market price $(€ / \mathrm{kg})$, did not have economic sustainability. According to FAO 2018, the species Mullus barbatus and Mullus surmuletus have shown a decrease in 2014, with a slight recovery in 2015. This situation is presented in this study because fishermen have not found a sustainable amount in the study area of these species.

The management of small-scale coastal fishing is challenging under the common fisheries policy [50], due to its complex nature and inter-regional differences, emerging from the specific biological and socio-economic characteristics. Fishermen, in order to protect their income, target species of less economic values, as observed in the present study. For instance, they caught large amounts of $B$. boops, which was a target species for them, but also caught $S$. cabrilla, which was not a target species but contributed to their income. Species availability seems, therefore, to determine the strategy employed by fishermen, as it was also previously reported in other areas [16,51,52]. As a result, the fishermen adjust their strategies based on the market demand, so as to make profit. Nevertheless, 
the aim of a satisfactory income affects fish stocks significantly. Thus, continuous monitoring by the common fisheries policy is a prerequisite for the adoption of relevant measures to preserve the fishing sector, including the adoption of environmentally friendly approaches to protect wild natural stocks. This is especially the case in the insular and coastal areas, where the small-scale fishing sector contributes highly to their economy.

Small-scale fisheries have been, historically, a major source of high-quality food, employment, and economic benefit for the coastal societies [46]. However, several studies warn about a severe shrinkage of these types of fisheries in several areas of the Mediterranean [16,24,53], raising concern for future viability. According to [46], the Greek Seas' catches of each stock either declined or collapsed in 2007, while [5] and [2] concluded that large-scale and recreational fisheries constitute the main threat to small-scale fisheries and coastal resources in Europe. Such threats are expected to particularly affect the Dodecanese Islands complex, which is considered one of the most heavily exploited sub-areas of the Aegean Sea. The implementation of reliable management plans and recursive monitoring protocols seem imperative to protect fish stocks and sustain small-scale coastal fishery, especially considering the key areas of Mediterranean fisheries, such as in this study area.

Author Contributions: For research articles with several authors, a short paragraph specifying their individual contributions must be provided. The following statements should be used "Conceptualization, K.R. and D.V.; Methodology, K.R.; Validation, K.R.; Formal Analysis, K.R.; Investigation, K.R.; Writing-Original Draft Preparation, K.R..; Writing-Review and Editing, K.R. and D.V.; Supervision, D.V.; Project Administration, K.R.

Funding: This research received no external funding.

Acknowledgments: The author would like to thank the fishermen of Kalymnos for their co-operation and valuable assistance.

Conflicts of Interest: The authors declare no conflict of interest.

\section{References}

1. Farrugio, H.; Oliver, P.; Biagi, F. An overview of the history, knowledge, recent and future research trend in Meditterranean fisheries. Sci. Mar. 1993, 57, 105-119.

2. Food and Agriculture Organization. The State of World Fisheries and Aquaculture. Meeting the Sustainable Development Goals; FAO: Rome, Italy, 2018.

3. Battaglia, P.; Romeo, T.; Consoli, P.; Scotti, G.; Andaloro, F. Characterization of the artisanal fishery and its socio-economic aspects in the central Mediterranean Sea (Aeolian Islands, Italy). Fish. Res. 2010, 102, 87-97. [CrossRef]

4. Battaglia, P.; Andaloro, F.; Consoli, P.; Peda, C.; Raicevich, S.; Spagnolo, M.; Romeo, T. Baseline data to characterize and manage the small-scale fishery (SSF) of an oncoming Marine Protected Area (Cape Milazzo, Italy) in the western Mediterranean Sea. Ocean Coast. Manag. 2017, 148, 231-244. [CrossRef]

5. Guyader, O.; Berthou, P.; Koutsikopoulos, C.; Alban, F.; Demanèche, S.; Gaspar, M.B.; Eschbaum, R.; Fahy, E.; Tully, O.; Reynal, L.; et al. Small scale fisheries in Europe: A comparative analysis based on a selection of case studies. Fish. Res. 2013, 140,1-13. [CrossRef]

6. Salas, S.; Gaertner, D. The behavioural dynamics of fishers: Management implications. Fish Fish. 2004, 5 , 153-167. [CrossRef]

7. Biseau, A.; Gondeaux, E. Apport des methods d'ordination en typologie des flottilles. J. Cons. Int. Explor. Mer. 1988, 44, 286-296. [CrossRef]

8. He, X.; Bigelow, K.A.; Boggs, C.H. Cluster analysis of longline sets and fishing strategies within the Hawaii-based fishery. Fish. Res. 1997, 31, 147-158. [CrossRef]

9. Pelletier, D.; Ferraris, J. A multivariate approach for defining fishing tactics from commercial catch and effort data. Can. J. Fish. Aquat. Sci. 2000, 57, 51-65. [CrossRef]

10. Ulrich, C.; Gascuel, D.; Dunn, M.R.; Le Gallic, B.; Dintheer, C. Estimation of technical interactions due to the competition for resource in a mixed-species fishery, and the typology of fleets and métiers in the English Channel. Aquat. Living Res. 2001, 14, 267-281. [CrossRef] 
11. Maynou, F.; Demertre, M.; Sanchez, P. Analysis of catch per unit effort by multivariate analysis and generalised linear models for deep-water crustacean fisheries off Barcelona (NW Mediterranean). Fish. Res. 2003, 65, 257-269. [CrossRef]

12. Ulrich, C.; Andersen, B.S. Dynamics of fisheries, and the flexibility of vessel activity in Denmark between 1989 and 2001. ICES J. Marine Sci. 2004, 61, 308-322. [CrossRef]

13. Garcia-Rodriguez, M.; Fernandez, M.A.; Esteban, A. Characterisation, analysis and catch rates of the small-scale fisheries of the Alicante Gulf (SE Spain) over a 10 years time series. Fish. Res. 2006, 77, 226-238. [CrossRef]

14. Martín, P.; Maynou, F.; Stelzenmüller, V.; Sacanell, M. A small-scale fishery near a rocky littoral marine reserve in the northwestern Mediterranean (Medes Islands) after two decades of fishing prohibition. Sci. Marina 2012, 76, 607-618. [CrossRef]

15. Castro, J.; Marín, M.; Pierce, G.J.; Punzón, A. Identification of metiers of the Spanish set-longline fleet operating in non-Spanish European waters. Fish. Res. 2011, 107, 100-111. [CrossRef]

16. Maynou, F.; Recasens, L.; Lombarte, A. Fishing tactics dynamics of a Mediterranean small-scale coastal fishery. Aquat. Living Res. 2011, 24, 149-159. [CrossRef]

17. Forcada, A.; Valle, C.; Sanchez-Lizaso, J.L.; Bayle-Sempere, J.T.; Corsi, F. Structure and spatio-temporal dynamics of artisanal fisheries around a Mediterranean marine protected area. ICES J. Marine Sci. 2010, 67, 191-203. [CrossRef]

18. Silva, L.; Gil, J.; Sobrino, I. Definition of fleet components in the Spanish artisanal fishery of the Gulf of Cadiz(SW Spain ICES division IXa). Fish. Res. 2002, 59, 117-128. [CrossRef]

19. Castro, J.; Marín, M.; Pérez, N.; Pierce, G.J.; Punzón, A. Identification of métiers based on economic and biological data: The Spanish bottom otter trawl fleet operating in non-Iberian European waters. Fish. Res. 2012, 125-126, 77-86. [CrossRef]

20. Samy-Kamal, M.; Forcada, A.; Sánchez-Lizaso, J.L. Trawling fishery of the western Mediterranean Sea: Métiers identification, effort characteristics, landings and income profiles. Ocean Coast. Manag. 2014, 102, 269-284. [CrossRef]

21. Quetglas, A.; Merino, G.; Ordines, F.; Guijarro, B.; Garau, A.; Antoni, M.G.; Oliver, P.; Massutí, E. Assessment and management of western Mediterranean small-scale fisheries. Ocean Coast. Manag. 2016, 133, 95-104. [CrossRef]

22. Leleu, K.; Pelletier, D.; Charbonnel, E.; Letourneur, Y.; Frédéric, B.; Boudouresque, F.C. Métiers, effort and catches of a Mediterranean small-scale coastal fishery: The case of the Côte Bleue Marine Park. Fish. Res. 2014, 154, 93-101. [CrossRef]

23. Marchal, P. A comparative analysis of métiers and catch profiles for some French demersal and pelagic fleets. ICES J. Marine Sci. 2008, 65, 674-686. [CrossRef]

24. Colloca, F.; Crespi, V.; Cerasi, S.; Coppola, S.R. Structure and evolution of the artisanal fishery in a southern Italian coastal area. Fish. Res. 2004, 69, 359-369. [CrossRef]

25. Stergiou, I.K.; Moutopoulos, K.D.; Soriguer, C.M.; Puente, E.; Lino, G.P.; Zabala, C.; Monteiro, P.; Errazkin, A.L.; Erzini, K. Trammel net catch species composition, ctach rates and métiers in southern European waters: A multivariate approach. Fish. Res. 2006, 79, 170-182. [CrossRef]

26. Tzanatos, E.; Dimitriou, E.; Katselis, G.; Georgiadis, M.; Koutsikopoulos, C. Composition, temporal dynamics and regional characteristics of small-scale fisheries in Greece. Fish. Res. 2005, 73, 147-158. [CrossRef]

27. Tzanatos, E.; Somarakis, S.; Tserpes, G.; Koutsikopoulos, C. Identifying and classifying small-scale fisheries métiers in the Mediterranean: A case study in the Patraikos Gulf, Greece. Fish. Res. 2006, 81, 158-168. [CrossRef]

28. Moutopoulos, K.D.; Ramfos, A.; Moukas, C.; Katselis, G. Description of a daily fishing activity from a small-scale fisherman in Central Greece (Korinthiakos Gulf). Intern. Aquat. Res. 2014, 6, 67. [CrossRef]

29. Katsanevakis, S.; Maravelias, C.D.; Vassilopoulou, V.; Haralabous, J. Boat seines in Greece: Landings profiles and identification of potential métiers. ICES J. Mar. Sci. 2010, 74, 65-76. [CrossRef]

30. Katsanevakis, S.; Maravelias, C.D.; Vassilopoulou, V. Otter trawls in Greece: Landing profiles and potential métiers. Mediterranean ICES J. Mar. Sci. 2010, 11, 43-59. [CrossRef]

31. Katsanevakis, S.; Maravelias, C.D.; Kell, L.T. Landings profiles and potential métiers in Greek set longlines. ICES J. Mar. Sci. 2009, 67. [CrossRef] 
32. Roditi, K.; Matsiori, S.; Vafidis, D. Valuation of drifting longlines fishing operations in the fleet of Kalymnos (Dodecanese, SE Aegean). Proccedings of the 13th ICZEGAR, Iracleio, Crete, 7-12 October 2015.

33. Sumaila, R.U.; Marsden, D.A.; Watson, R.; Pauly, D. A Global Ex-vessel Fish Price Database: Construction and Applications. J. Bioecon. 2007, 9, 39-51. [CrossRef]

34. Pinellio, D.; Gee, J.; Dimech, M. Handbook for Fisheries Socioeconomic Sample Survey-Principles and Practice; FAO Fisheries and Aquaculture Technical; Paper No. 613; FAO: Rome, Italy, 2017.

35. Food and Agricultural Organization. Measuring and appraising capacity in fisheries: Framework, analytical tools and data aggregation. FAO Fish 2004. No. 994. FIPP/C994(En).

36. Zimmermann, F.; Heino, M. Is size-depentent pricing prevalent in fisheries? The case of Norwegian demersal and pelagic fisheries. ICES J. Marine Sci. 2013, 70, 1389-1395. [CrossRef]

37. Swartz, W.; Sumaila, R.; Watson, R. Global Ex-vessel Fish Price Database Revisited: A New Approach for Estimating 'Missing' Prices. Environ. Resour. Econ. 2013, 56, 467-480. [CrossRef]

38. Common Fishery Policy (CFP). Fleet Register. 2013. Available online: http://ec.europa.eu/fisheries/fleet/ index.cfm?method=Search.SearchSimple\&country=GRC (accessed on 5 January 2013).

39. Mazzoldi, C.; Sambo, A.; Riginella, E. The Clodia database: A long time series of fishery data from the Adriatic Sea. Artic. Sci. Data 2014. [CrossRef] [PubMed]

40. Flaatten, O.; Heen, K. Fishing vessel profitability and local economic link-the case of Norwegian trawlers. Mar. Policy 2004, 28, 451-457. [CrossRef]

41. Food and Agricultural Organization. Socio-economic analysis of Lebanese fishing fleet. EastMed Technical Documents No. GCP/INT/041/E-GRE-ITA/TD-16. Athens. In Scintific and Institutional Cooperation to Support Responsible Fisheries in the Eastern Mediterranean; FAO: Rome, Italy, 2013; 78p, Available online: http://www.fao.org/3/ar250e/ar250e.pdf (accessed on 11 September 2018).

42. Food and Agricultural Organization. Socio-Economic analysis of Egyptian fisheries: Options for improvement EastMed Technical Documents No. 19. GCP/INT/041/EC-GRE-ITA/TD-19. Athens. In Scientific and Institutional Cooperation to Support Responsible Fisheries in the Eastern Mediterranean; FAO: Rome, Italy, 2014; 127 p.

43. Food and Agricultural Organization. A subregional analysis of the socio-economic situation of the Eastern Mediterranena fisheries. In EastMed Technical Documents; No. 22; FAO: Rome, Italy, 2016; 70p.

44. Hoa, T.T. Open-Access Insore Fisheries-the Economic Performance of the Purse Seine Fisheries in Nha Trang, Vietnam; The Norwegian College of Fishery Science, Univeristy of Tromso, Norway \& Nha Trang University: Nha Trang, Vietnam, 2012.

45. Herrero, I. Risk and strategy of fisheries alternatively exloiting sea bream and tuna in the Gibraltar Strait from an efficiency perspective. ICES J. Mar. Sci. 2004, 61, 211-217. [CrossRef]

46. Tsikliras, C.A.; Tsiros, Z.V.; Stergiou, I.K. Assessing the state of Greek marine fisheries resources. Fish. Manag. Ecol. 2013, 20, 34-41. [CrossRef]

47. Palmer, M.; Tolosa, B.; Grau, M.A.; Mar, G.M.; Obregon, C.; Morales-Nin, B. Combining sale records of landings and fisheries knowledge for presenting metiers in a small-scale, multi-gear, multispecies fishery. Fish. Res. 2017, 195, 59-70. [CrossRef]

48. Colloca, F.; Crespi, V.; Cerasi, S.; Coppola, S.R. Evolution of the Artisanal Fishery in Cilento, Italy-Case Study; FAO: Rome, Italy, 2003.

49. Merino, G.; Morales-Nin, B.; Maynou, F.; Grau, M.A. Assessment and bioeconomic analysis of the Majorca (NW Mediterranean) trammel net fishery. Aquat. Living Resour. 2008, 21, 99-107. [CrossRef]

50. Leite, L.; Pita, C. Rewview of participatory fisheies management arrangements in the European Union. Marine Policy 2016, 74, 268-278. [CrossRef]

51. Salda, A.; Salas, S.; Arce-Ibarra, M.A.; Torres-Irine, E. Fishing operations and adaptive strategies of small-scale fisheries: Insights for fisheries management in data-poor situations. Fish. Manag. Ecol. 2017, 24, 19-32. [CrossRef]

52. Guillen, J.; Maynou, F. Characterisation of fish species based on ex-vessel prices and its management implications: An application to the Spanish Mediterranean. Fish. Res. 2015, 167, 22-29. [CrossRef]

53. Lloret, J.; Font, T. A comparative analysis between recreational and artisanal fisheries in a Mediterranean coastal area. Fish. Manag. Ecol. 2013, 148-160. [CrossRef] 
(C) 2019 by the authors. Licensee MDPI, Basel, Switzerland. This article is an open access article distributed under the terms and conditions of the Creative Commons Attribution (CC BY) license (http://creativecommons.org/licenses/by/4.0/). 